Abstracta Iranica Abstracta Iranica

Revue bibliographique pour le domaine irano-aryen

Volume 31 | 2011

Comptes rendus des publications de 2008

\title{
Andarznāme-hā-ye irānī. Tehrān, Daftar-e pažūheš- hā-ye farhangī. 1386/2007, 116 p. (Az Irān če midānam ? 82) [Les recueils parénétiques iraniens]
}

Samra Azarnouche

\section{(2) OpenEdition}

Journals

Édition électronique

URL : http://journals.openedition.org/abstractairanica/39763

DOI : 10.4000/abstractairanica.39763

ISSN : 1961-960X

Éditeur :

CNRS (UMR 7528 Mondes iraniens et indiens), Éditions de l'IFRI

Édition imprimée

Date de publication : 15 mai 2011

ISSN : 0240-8910

Référence électronique

Samra Azarnouche, «Andarznāme-hā-ye irānī. Tehrān, Daftar-e pažūheš-hā-ye farhangī. 1386/2007,

116 p. (Az Irān če midānam ? 82) [Les recueils parénétiques iraniens] », Abstracta Iranica [En ligne],

Volume 31 | 2011, document 265, mis en ligne le 11 octobre 2012, consulté le 26 septembre 2020.

URL : http://journals.openedition.org/abstractairanica/39763 ; DOI : https://doi.org/10.4000/

abstractairanica.39763

Ce document a été généré automatiquement le 26 septembre 2020.

Tous droits réservés 


\section{Andarznāme-hā-ye irānī. Tehrān, Daftar-e pažūheš-hā-ye farhangī. 1386/2007, 116 p. (Az Irān če midānam ? 82) [Les recueils parénétiques iraniens]}

\section{Samra Azarnouche}

Ce numéro de la collection didactique «Que sais-je sur l'Iran? " présente une vision globale d'un genre littéraire iranien composé de textes parénétiques et d'écrits sapientiaux. Qu'il soit de portée religieuse ou pragmatique, l'andarz peut se décliner sous plusieurs formes : phrases gnomiques et aphorismes, allégories ou maximes, avec ou sans récit cadre, etc. Après un bref aperçu des thèmes et des textes les plus représentatifs du genre dans la littérature pré-islamique (notamment en pehlevi, les plus célèbres étant le VII ${ }^{\mathrm{èm}}$ livre du Dēnkard et les andarz d'Adurbād Mahraspandān), l'A. explore les chemins par lesquels l'andarz iranien s'est immiscé par le biais de la traduction dans la littérature arabe, avant de se pérenniser dans les recueils de sagesse islamique, dans les Miroirs des princes, et dans des chefs-d'œuvre persans en prose comme en vers, allant de Sa'dī à Sanā'ī, ou de Ǵazzālī à Qā’ānī.

\section{INDEX}

Thèmes : 11.1.0. Généralités 
AUTEURS

SAMRA AZARNOUCHE

Paris 